\title{
P02.179. Effects of an integrated yoga program on mood, perceived stress, quality of life and immune measures in HIV patients: a pilot study
}

\author{
R Rao ${ }^{\text {** }}$ U Deb², N Raghuram², N Hongasandra Rama Rao², A Burke ${ }^{3}, \mathrm{~F} \mathrm{Hecht}^{3}$ \\ From International Research Congress on Integrative Medicine and Health 2012 \\ Portland, Oregon, USA. 15-18 May 2012
}

\section{Purpose}

HIV seropositive subjects experience psychological distress that impacts their quality of life and disease progression. In this pilot study we evaluated the effects of a yoga intervention on mood, perceived stress, quality of life and immune responses in HIV+ subjects.

\section{Methods}

Seventy HIV+ subjects not on HAART and with a CD4 count $>250$ were recruited from a HIV referral center in Bangalore to participate in a two arm randomized waitlist control trial. Subjects were randomized to receive a yoga intervention $(\mathrm{N}=36)$ or serve as wait-list controls $(\mathrm{N}=$ 34 ). While the yoga group received an integrated set of one hour daily yoga therapy sessions (asanas, pranayama and meditation) for 3 months, the waitlist control group received only education and counseling during clinic visits. Both groups were assessed at baseline and after the intervention period using the Hospital Anxiety and Depression Scale, Perceived Stress Scale, the HIV WHO QoL BREF, the Positive and Negative Affect Schedule; CD4, CD8 counts were measured using flow cytometry, and viral load using RT PCR. There were 11 dropouts in yoga and 9 in the control group.

\section{Results}

Data were analyzed using the intention to treat principle. There was a significant decrease in perceived stress $(\mathrm{p}=$ $0.001)$ and psychological distress $(\mathrm{p}=0.04)$, and an increase in positive affect $(\mathrm{p}=0.003)$ in the yoga group compared to waitlist controls on ANCOVA with the respective baseline measure as a covariate. There was a

${ }^{1}$ HCG Bangalore Institute of Oncology, Bangalore, Karnataka, India Full list of author information is available at the end of the article decrease in self-report anxiety $(\mathrm{p}=0.02)$, depression $(\mathrm{p}=0.009)$, negative affect $(\mathrm{p}=0.02)$ and fatigue $(\mathrm{p}=0.001)$ in the yoga group alone on paired $t$-test.

\section{Conclusion}

The results suggest benefit with yoga in reducing psychological distress and improving quality of life in HIV seropositive patients. However, larger randomized controlled trials are needed to validate these findings.

\section{Author details}

${ }^{1}$ HCG Bangalore Institute of Oncology, Bangalore, Karnataka, India. ${ }^{2}$ Swami Vivekananda Yoga Anusandhana Samsthana, Bangalore, India. ${ }^{3}$ Osher Center for Integrative Medicine, UCSF, San Francisco, USA.

Published: 12 June 2012

doi:10.1186/1472-6882-12-S1-P235

Cite this article as: Rao et al.: P02.179. Effects of an integrated yoga program on mood, perceived stress, quality of life and immune measures in HIV patients: a pilot study. BMC Complementary and Alternative Medicine 2012 12(Suppl 1):P235.

Submit your next manuscript to BioMed Central and take full advantage of:

- Convenient online submission

- Thorough peer review

- No space constraints or color figure charges

- Immediate publication on acceptance

- Inclusion in PubMed, CAS, Scopus and Google Scholar

- Research which is freely available for redistribution

\section{Biomed Central}

(c) 2012 Rao et al; licensee BioMed Central Ltd. This is an Open Access article distributed under the terms of the Creative Commons Attribution License (http://creativecommons.org/licenses/by/2.0), which permits unrestricted use, distribution, and reproduction in any medium, provided the original work is properly cited. 